\title{
ІСТОРІЯ БIOXIMIÏ
}

Той, хто робить відкриття, бачить те саме, що бачать усі, але думає так, як не думають інші

Альберт Сент-Дерді

\section{ВИНАХІДНИЦЬКА ДІЯЛЬНІСТЬ АКАДЕМІКА НАН УКРАЇНИ МАКСИМА ФЕДОТОВИЧА ГУЛОГО}

110-річчю від дня народження присвячується

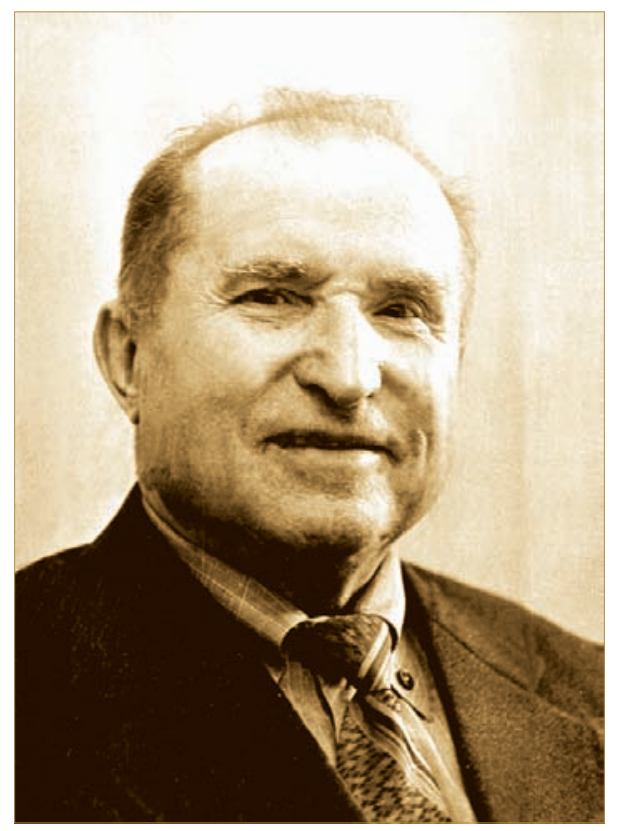

М. Ф. Гулий

(03.03.1905-23.05.2007)

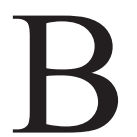

идатний вчений і педагог, талановитий організатор науки, один із фундаторів вітчизняної біохімії академік Максим Федотович Гулий по праву належить до славетної плеяди дослідників, які завдяки своїй подвижницькій праці та яскравим науковим досягненням заслуговують на звання класиків науки.

Наукові інтереси М. Ф. Гулого охоплювали надзвичайно широке коло різноманітних проблем функціональної біохімії. Його роботи завжди стосувались найважливіших питань часу. У 30-ті роки - це проблеми збалансованого харчування й вуглеводного обміну в м'язах, у повоєнні роки - вивчення фізіологічної ролі циклу трикарбонових кислот, визначення зв'язку між обміном пуринів і злоякісним ростом, питання регуляції біосинтезу протеїнів і ліпідів. М. Ф. Гулим зроблено фундаментальний внесок до сучасного розуміння метаболічних перетворень одновуглецевих сполук у гетеротрофних організмів; він безпосередньо причетний до зародження вітчизняної молекулярної біології та імунохіміі.

Одним із напрямів науково-дослідної роботи М. Ф. Гулого була розробка оригінальних методів виділення, очищення і кристалізації індивідуальних протеїнів тваринного $\mathrm{i}$ мікробного походження. У співпраці 3 колективом було вдосконалено методи їх кристалізаціїі, вивчено властивості багатьох індивідуальних протеїнів, а саме - АTФ- 
аргінінкінази, фосфофруктокінази, альдолази, дегідрогенази-3-фосфорної кислоти, -гліиерофосфатдегідрогенази, енолази, гемоглобіну та інших. Роботи, пов'язані з вивченням кристалічних протеїнів, було визнано у всьому світі. Їх перекладено і опубліковано в авторитетних іноземних виданнях, результати цих дослідів доповідались М. Ф. Гулим на конгресах, симпозіумах, з’їздах та конференціях.

Результати досліджень опубліковано в 9 монографіях, 560 наукових статей і тез, 27 патентах на винаходи. Під керівництвом М. Ф. Гулого виконано та захищено 80 кандидатських та 10 докторських дисертацій. М. Ф. Гулий створив потужну школу науковців, серед яких $\epsilon$ чимало фахівців 3 найвищими науковими званнями, в тому числі академік НАН та АМН України С. В. Комісаренко, академік НАН України Г. Х. Мацука, академік НАН та НААН України Д. О. Мельничук та багато інших знаних науковців.

Сповідуючи життєве i наукове кредо «Біохімія на користь людству», Максим Федотович вважав, що «справжні фундаментальні дослідження, як правило, рано чи пізно приведуть до вирішення тих чи інших практичних завдань, які ставить перед людством життя». Саме тому практичні здобутки наукової роботи М. Ф. Гулого виявилися такими самими вагомими, масштабними та різноманітними, як $\mathrm{i}$ наукові.

В цій статті ми коротко проаналізуємо прикладні розробки, які він розпочав ще в аспірантурі (1929-1932 рр.) і продовжував впродовж всього свого довгого творчого життя. Перші його роботи стосуються використання досягнень біохімії в тваринництві.

Одним із найважливіших завдань $\mathrm{y}$ тваринництві завжди було питання зберігання (консервування) кормів за мінімальної втрати в них поживних речовин, передусім протеїнів. Працюючи із силосними кормами, М. Ф. Гулий виявив, що додавання амонійних солей в силос під час його закладання зменшує втрати органічних азотистих речовин - протеїнів, а іноді навіть збільшує їх вміст. Він детально описав розроблений ним метод, пов'язаний зі збагаченням корму на органічні азотні речовини внаслідок внесення до нього мінерального азоту і видав великим тиражем брошуру з інструкцією про це нововведення, яку було розіслано в усі земельні відділи областей України. На Київській обласній сільськогосподарській станції «Терезіно» було закладено великі запаси кукурудзяного силосу із добавкою амонійних солей, які зрештою за всіма показниками (вміст неорганічних кислот, протеїнів, органічних кислот, амінокислот) були кращими за контрольні. Нині иеей метод широко використовують $і$ в інших господарствах країни.

Максим Федотович також вважав важливим вирішення за допомогою науки проблем підвищення продуктивності тварин, які завжди стояли перед людством і $є$ актуальними й сьогодні. Одне 3 таких питань - збільшення жиру в молоці.

Для підвищення жирності молока в корів М. Ф. Гулий запропонував додавати до їжі три дні на місяць по одному літру пивної гущі, яка залишається після виробництва пива. Головна складова цієї гущі - живі дріжджі. Справа в тому, що дріжджі зброджують иукри у спирт, що в організмі людини і тварин перетворюється переважно в оитову кислоту, яка є субстратом для синтезу жирних кислот. Крім того під час бродіння утворюється $\alpha$-глічерофосфат, який є джерелом глічеролу - другого компоненma жирів. Триденне згодовування тваринам пивних дріжджів слід повторювати щомісяця i тоді жирність молока збільшуватиметься на 20-25\% в період всієї лактації. Цей метод підвищення жирномолочності корів, який було розроблено в Інституті біохімії М. Ф. Гулим зі співробітниками, виправдав себе на практиці. Згодом цей метод було перевірено в Румунії і Чехословаччині з такими самими позитивними результатами.

Виходячи 3 теоретичного постулату, що $\mathrm{CO}_{2} є$ основою життя, Максим Федотович не оминув використати його у вирішенні проблеми підвищення надоїв молока в корів. Численні дослідження ролі вуглекислоти в організмі тварин дало практичні результати: М. Ф. Гулий зі співробітниками створили препарати «Карбоксилін» та декілька його модифікацій (МП-15 та МП-30) - мінеральні амонійні препарати, які значно підвищують продуктивність буквально всіх сільськогосподарських тварин і птиці. Виявилось, що відповідними препаратами можна або активувати, або гальмувати синтез органічних речовин. Зокрема, «Карбоксилін» стимулює процес карбоксилю- 
вання, за якого вуглець неорганічних речовин $\left(\mathrm{CO}_{2}\right)$ перетворюється в організмі тварин на вуглець органічних сполук. Науковцями було доведено, що підвищення ступеня карбоксилювання сприяе збільшенню біосинтезу протеїнів, жирів $i$ иукрів в організмі, завдяки чому забезпечується підвищення продуктивності сільськогосподарських тварин. У разі згодовування «Карбоксиліну» тваринам збільшуються надої молока в корів під час лактащіï, а також приріст живої маси під час відгодівлі великої рогатої худоби, овець, свиней, птииі.

Препарати, розроблені на базі вуглекислоти - «Карбоксилін» та амонійно-мінеральні препарати (МП-15 та МП-30), на практиці, за ix широкого використання, виявились дуже ефективними. За здійсненими підрахунками в Інституті економіки ім. Шліхтера Українського відділення ВАСГНІЛ та Інституту економіки Академії наук УРСР їх застосування давало до 10 карбованців прибутку на 1 карбованець витрат. У 22 областях із 25 областей України було збудовано заводи з випуску «Карбоксиліну». За три роки, що передували перебудові, в Україні його вироблялось 30000 т щорічно.

Оскільки препарат був недорогим, доступним і достатньо ефективним, що було доведено в процесі проведення досліджень у відомчих господарствах, за рішенням Міністерства сільського господарства СРСР його було впроваджено на всій території Радянського Союзу у всіх районах із розвинутим тваринництвом. Почалося широке будівництво підприємств 3 виробництва і впровадження у тваринництво препарату «Карбоксилін», насамперед в Україні, Молдові, Латвії та Росії. Виробництво і використання його продовжувалось до розпаду СРСР.

Ці дослідження було відзначено в 1985 р. Державною премією УРСР в галузі науки i техніки («За розробку і впровадження в практику препаратів, які підвищують продуктивність сільськогосподарських тварин і птиці»). Лауреатами Державної премії України в галузі науки і техніки стали М. Ф. Гулий і Д. О. Мельничук.

Не менш вагомими $є$ наукові розробки Максима Федотовича Гулого, які знайшли впровадження в медицину.

Якщо згадувати їх у хронологічному порядку, то слід почати із препарату «Мікроцид» та історії його створення. Свого часу членикореспонденти АН УРСР М. М. Підоплічко і
В. Й. Білай, вирощуючи міцелій гриба Penicillum vitale на середовищі, яке містило глюкозу, показали, що цей мікроорганізм продукує активну речовину із властивостями антибіотика, якій вони дали назву «Мікроцид». Водночас доктор біологічних наук Е. Т. Сорені показав, що ця речовина є флавіновим ензимом. Маючи певний досвід експериментальної роботи 3 виділення й очищення тканинних протеїнів, зокрема кристалічних препаратів гліколітичних ензимів альдолази і фосфофруктокінази (роботи М. Ф. Гулого з П. Д. Дворніковою), колектив науковців Інституту біохімії під керівництвом М. Ф. Гулого одержав цей флавіновий ензим із міцелію P. vitale в кристалічному стані і довів, що він є глюкозооксидозою.

Отже, в Інституті біохімії було розроблено метод виділення глюкозооксидази 3 культуральної рідини і міцелію гриба в сухому високоочищеному стані та в кристалічній формі.

За створення медичного препарату «Мікроцид» М. М. Підоплічно, В. Й. Білай, Е. Т. Сорені і М. Ф. Гулий в 1952 р. одержали Державну премію СРСР.

Таким чином, результатом чієї спільної роботи було розроблення $і$ налагодження виробниитва медичного препарату - антибіотика «Мікроцид», який широко використовувався в медичній практиці.

Крім цього, в Інституті біохімії М. Ф. Гулим було виділено і одержано в кристалічному стані ензим каталазу із гриба P. vitale, а пізніше розроблено метод пероксидно-каталазного знебарвлення крові тварин, який було широко впроваджено в практику на м'ясокомбінатах країни для одержання високоякісного харчового протеїну як джерела иінної добавки в ковбасах. А для широкомасштабного виробництва глюкозооксидази і каталази $3 P$. vitale було побудовано цех на Косарському спиртовому заводі Черкаської області.

За розроблення теоретичних основ та технології промислового виробництва $i$ застосування високоочищених ензимів глюкозооксидази і каталази та створення на їх основі технології пероксидно-каталазного знебарвлення крові як додаткового джерела харчового протеїну М. Ф. Гулого і Р. Г. Дегтяр у 1978 р. було відзначено Державною премією УРСР.

Крім вищезазначених промислових технологій розроблено метод визначення глюко- 
зи для клінічних потреб та одержано стабільний реактив для ензимного аналізатора глюкози безперервної дії. Створено екологічно чисту технологію одержання молекулярного кисню. За результатами роботи опубліковано монографію «Фермент глюкозооксидаза и его применение» (Наук. думка, 1964).

У подальшому після деякої модифікації препарату «Карбоксилін», створеного, як ми відзначали вище, для підвищення продуктивності сільськогосподарських тварин, було розроблено і застосовано в медичній практиці препарат «Намацит», який посилює окисно-відновні та біосинтетичні процеси, стимулює метаболізм унаслідок інтенсифікації карбоксилювання, забезпечує вищий рівень функціонування циклу трикарбонових кислот у тканинах, що обумовлює антигіпоксичну дію препарату. Тобто «Намацит» виявився адаптогенним препаратом, який стимулює регенерацію крові за анемій, м'яких тканин у разі поранень і кісток за переломів, допомагає у лікуванні незагоюваних виразок тощо. Він пройшов клінічні випробування і рекомендований для практичного застосування як «Adanтогенний препарат та спосіб його одержання» (патент України, 1998 р.). (Зміна назви «Намаuчит» на «Адаптогенний препарат» стала предметом гострої дискусії між М. Ф. Гулим і проф. М. Л. Тараховським, який на той час праиював у фармкомітеті МОЗ Украӥни. Про ие Максим Федотович ділиться з читачем на 69-70 сторінках в книзі «Академік Максим Федотович Гулий (до 100-річчя від дня народження)», Київ, 2005 р.).

Максим Федотович не безпідставно вважав, що медицина $є$ широкою і глибоко теоретичною та практичною наукою, в розвитку якої велику роль відіграє біохімія. Блискучим підтвердженням цієї думки можуть бути i наступні наукові розробки колективу науковців під його керівництвом.

Дослідження алкоголізму і наркоманії показали, що це хвороби обміну речовин. Виходячи 3 цього, М. Ф. Гулий зі співробітниками розробили антиалкогольний препарат «Медихронал», а на основі сумісної дії «Медихроналу» i «Намациту» було розроблено і запропоновано у виробництво препарат антинаркотичної дії - «Медицит».

Алкоголізм - це не лише медична, але й важлива соціальна проблема, якою переймають- ся уряди багатьох держав. Але різні обмеження типу «сухого закону» і суворі покарання не мають великого успіху. Майже 15 років М. Ф. Гулий з колегами досліджував цю проблему і одержав важливі результати, які успішно реалізував на практиці. Теоретичним підгрунтям цієї проблеми було те, що алкоголізм є хворобою обміну речовин. Оскільки етанол у живому організмі перетворюється на токсичний ацетальдегід, який і сприяє сп'янінню, то М. Ф. Гулий вважав, що хронічний алкоголізм пов'язаний з високим рівнем ацетальдегіду в організмі, якому притаманний накопичувальний ефект внаслідок повільного метаболічного виведення. Саме тому алкоголікам не потрібні високі дози етанолу, аби сп'яніти, достатньо лише трохи додати до того, що в організмі накопичено.

З огляду на це і було запропоновано механізм дії розробленого протиалкогольного препарату «Медихронал», який містить компоненти, здатні зв'язувати ацетальдегід і сприяти його окисленню, отже, й знімати алкогольну інтоксикацію. Складові компоненти препарату (гліцин, глюкоза, форміат) є природними метаболітами, унаслідок чого нормалізується порушений за умов алкогольної інтоксикації обмін речовин.

На «Спосіб одержання антиалкогольного nрепарату «Медихронал» у 1990 р. одержано авторське свідоцтво СРСР. Він захищений патентом України від 1999 р. як винахід, що належить до хіміко-фармацевтичної промисловості, а саме до виробництва антиалкогольних препаратів. Одержаний відповідно до винаходу препарат може бути використаний у патогенетичній терапії хронічного алкоголізму.

I тут вважаємо доречним коротко зупинитися на історії цього винаходу. Прототипом його був спосіб одержання антиалкогольного препарату ГГФ, який в цьому ж науковому колективі спочатку одержували простим змішуванням його інгредієнтів, а саме: глюкози, гліщину (амінооцтової кислоти - АОК), форміату натрію (натрій мурашиновокислий - НМК) у співвідношеннях $5: 2: 1$. Така суміш потребує швидкого використання. Але цей метод одержання препарату ех teтpore не може бути використаний в промислових умовах тому, що глюкоза є сильним окислювачем і швидко розщеплює одержану суміш. До того ж термін зберігання такого препарату менше одного місяця. Крім того, зниження вмісту етанолу й ацетальдегіду 
в крові як основних показників антиалкогольної дії за використання ГГФ було недостатньо ефективним.

Тому перед авторами винаходу було поставлено завдання розробити спосіб одержання антиалкогольного препарату, який давав би можливість шляхом підбору співвідношення компонентів препарату, температурних $і$ часових режимів, окремого гранулювання і пакетування отримати препарат з високою антиалкогольною ефективністю і строком зберігання не менше двох років.

Внаслідок кропіткої, багаторічної дослідницької роботи колективу науковців на чолі з академіком М. Ф. Гулим це завдання було виконано. До роботи було також залучено медиків високої кваліфікації під керівництвом В. М. Синицького.

Додавання 20\%-го розчину полівінілпіролідону (ПВП) певної концентрації окремо до глюкози та окремо до суміші амінооцтової кислоти і натрію мурашиновокислого 3 метою отримання вологих гранул, сушіння у заданих температурних режимах до вологості не більше $1 \%$, сухе гранулювання і диференційне дозування дало можливість підвищити антиалкогольну дію препарату і збільшити строк його зберігання до двох років.

В експерименті антиалкогольну дію препарату «Медихронал» у порівнянні 3 ГГФ оцінювали за зниженням вмісту ацетальдегіду й адреналіну, за нормалізацією вмісту норадреналіну i активністю ензимів, які окислюють етанол (алкогольдегідрогеназа) i ацетальдегід (альдегіддегідрогеназа).

Експериментальні дослідження в лабораторних умовах показали, що введення щурам 20\%-го розчину етанолу 3 розрахунку 4 г/кг маси тварин, призводило до того, що вміст ацетальдегіду в крові через 60 хв підвищувався майже в 12 разів, а вміст норадреналіну - в середньому на $40 \%$ порівняно 3 контролем. Введення тваринам одночасно з етанолом препаратів ГГФ або «Медихроналу» $(0,6$ г на 1 кг маси тварин) значно знижувало вміст досліджуваних компонентів у крові. Але протиалкогольний ефект за введення «Медихроналу» був значно вищим у порівнянні з ефектом від застосування суміші ГГФ.

Дослідження, проведені на щурах із хронічною алкогольною інтоксикацією, показали, що у разі введення тваринам пре- парату «Медихронал» у крові тварин вміст ацетальдегіду знижувався в 2 рази, активність алкогольдегідрогенази в 1,5 раза, нормалізувалась активність альдегіддегідрогенази. Ефект за введення тваринам ГГФ був значно меншим.

Використання препарату «Медихронал» в клінічних умовах показало, що вже на наступний день після прийому препарату у хворих на хронічний алкоголізм значно полегшувалась абстинентна симптоматика: хворі ставали спокійнішими, зникала роздратованість, з'являвся апетит, нормалізувався сон. Повністю ці явища зникали на кінець третьої доби.

Аналіз одержаних результатів показав, що під час лікування хронічного алкоголізму препаратом «Медихронал» значно швидше зникають явища абстиненції, у крові хворих ефективніше знижується вміст етанолу, ацетальдегіду i діоксифенілаланіну (ДОФА) порівняно із застосуванням ГГФ.

Отже, висновок із експериментів був таким: антиалкогольний препарат «Медихронал» впливає на основні патогенетичні механізми формування алкоголізму, нормалізує обмін етанолу, призводить до детоксикації організму i активує функціональну активність центральної нервової системи у хворих на хронічний алкоголізм. Препарат не містить чужорідних для організму речовин, складається виключно 3 метаболітів, які постійно беруть участь в обміні речовин організму. Він рекомендується для профілактики алкогольного сп'яніння, як протверезний засіб, для запобігання гострих абстинентних станів і усунення фізичної залежності за хронічного алкоголізму, для знімання патологічного потягу до алкоголю.

Клінічні дослідження показали його високу лікувальну ефективність як за кількістю хворих, що позбавились алкогольної залежності, так і за тривалістю ремісії. Антиалкогольний препарат «Медихронал» у рекомендованих дозах не виявляє побічної і шкідливої дії на організм людини.

Отже, було створено та доведено до промислового виробництва принципово новий за механізмом дії лікувальний препарат «Медихронал», подвійний ефект якого забезпечує патогенетичну терапію і вторинну профілактику хронічного алкоголізму, а також дезінтоксикацію та зняття абстинентних станів. 
Одержане співробітниками i колегами М. Ф. Гулого наукове обгрунтування використання «Медихроналу» для лікування алкоголізму дозволило їм переконати фармацевтичних працівників $3 A T$ «Фармацевтична фірма «Дарниия» впровадити його у виробниитво і успішно (за лічензійним договором із Інститутом біохімії ім. О. В. Палладіна) випускати в промислових обсягах (спочатку вони відмовилися ие робити, боячись збитковості). Зараз препарат «Медихронал» можна вільно придбати в кожній аптеці України.

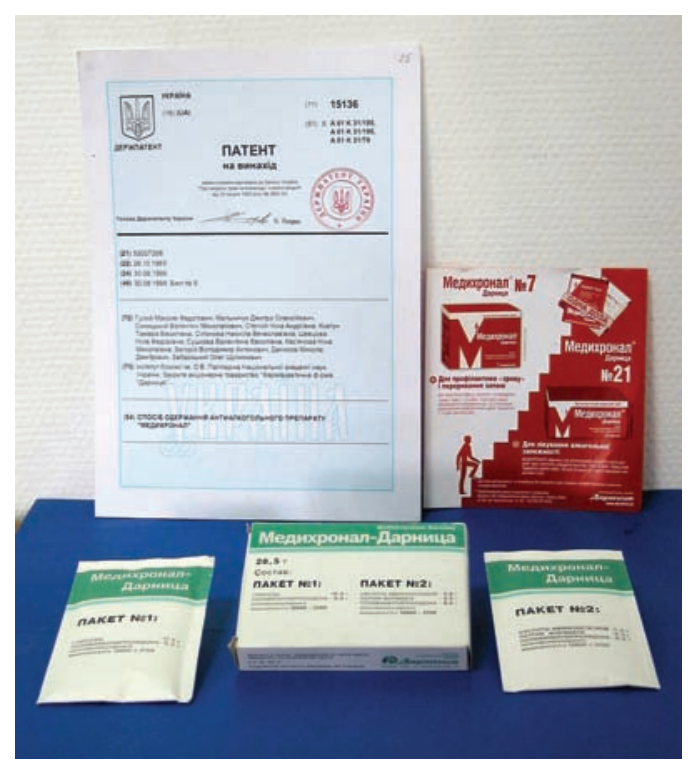

Успіхи у створенні препарату для лікування алкоголізму стимулювали до вивчення тих змін в обміні речовин, що розвиваються в організмі за наркотичної, переважно опіатної залежності.

Однотиповість формування багатьох проявів алкоголізму i наркоманії, взаємозамінюваність алкоголю та деяких наркотичних речовин, відсутність абстинентного синдрому під час заміни одного з них іншим, свідчило про можливість існування загальних ланцюгів у механізмах патогенезу алкогольної та наркотичної залежності. Показано, що внаслідок тривалого впливу морфіну в тварин спостерігаються значні порушення окисних $\mathrm{i}$ біосинтетичних процесів, що є важливою складовою патогенезу виникнення наркотичної залежності. Встановлено можливість певної нормалізації зазначених порушень за допомогою деяких природних сполук. На основі сумісної дії «Медихроналу» і «Намациту» розроблено $\mathrm{i}$ запропоновано препарат антинаркотичної дії «Медицит».

Останній може ефективно використовуватися для лікування наркотичної залежності, але впроваджувати його у виробництво (до речі, як і препарату «Намацит») фармацевтичні підприємства відмовляються, побоюючись збитковості.

Науковий колектив, очолюваний М. Ф. Гулим, постійно розробляв питання загальнобіологічного характеру. Це стимулювало дослідження механізмів метаболічної регуляції біосинтезу протеїнів у тварин під час різноманітних екстремальних впливів. Серед робіт М. Ф. Гулого, пов'язаних із вивченням структурних змін протеїнів, важливе місце належить дослідженням колагену - основного компонента сполучнотканинного матриксу, який створює мікрооточення клітин усіх типів. Особливо цікаві дані одержали науковці, котрі під керівництвом М. Ф. Гулого вивчали лейкоз. Саме до патогенезу останнього безпосередньо причетний колаген як складова мікрооточення клітин гемопоетичної лінії в стромально-гемопоетичному комплексі кісткової тканини. Вони показали, що на стадії розгорнутого лейкозу синтезується колаген, який відрізняється від свого нормального аналога за амінокислотним i субодиничним складом, молекулярною масою, поверхневим зарядом та вмістом вуглеводного компонента. Дослідники встановили, що виникнення структурних розбіжностей в позаклітинному матриксі супроводжується порушенням обміну речовин та зміною вмісту метаболітів.

Вивчаючи метаболічні процеси за гострого лейкозу в дітей, науковці з'ясували, що захворювання супроводжується також значним зниженням проміжних продуктів ияиклу трикарбонових кислот у крові, глибоким порушенням біосинтезу протеїнів і низки важливих метаболітів, а також сильним хронічним ацидозом, який, у свою чергу, супроводжується порушенням синтезу протеїнів й мінерального обміну. За лейкозу спостерігаються негативні зміни в мінеральному обміні, передусім, кальцію. Все це разом є причиною збіднення кісток на кальцій, що призводить до остеопорозу та їх ламкості. 
Фундаментальні дослідження колагенових структур стромально-гемопоетичного комплексу, з позиції патогенетичного чинника розвитку лейкозу в тварин та людей, призвели до розробки нового лікарського препарату «Коректин».

Клінічні випробування показали доцільність його включення до базисної хіміотерапії в онкогематології як засобу для лікування супутніх уражень опорно-рухового апарату, регенерації кісткової тканини, підвищення антибактеріального захисту за рахунок гранулоцитів крові, дезінтоксикації організму i скороченню строків виходу в ремісію. Вони також засвідчили, що введення препарату до базисної хіміотерапії сприяє скороченню термінів відновлення опорно-рухових функцій і запобігає розвитку кісткових уражень у процесі досягнення ремісії. Його застосування пом'якшує або навіть усуває й інші патологічні симптоми. Навіть у тяжких випадках захворювання, якщо тільки патологічний процес не набув незворотної форми, під впливом препарату наставала чітко виражена ремісія.

Величезний внесок у розроблення і створення цього препарату зробили співробітники Інституту біохімії ім. О. В. Палладіна НАН України, а вирішальну роль у впровадженні в практику способу лікування «Коректином» відіграли співробітники Центру радіаційної медицини АМН України.

На жаль, препарат «Коректин», незважаючи на позитивні клінічні результати, спіткала така сама доля, як «Намаџит» і «Медиџит». Сьогодні він все ще не виробляється у промислових масштабах.

Слід наголосити на тому, що до моменту створення М. Ф. Гулим вищезазначених лікарських препаратів не було відомо інших засобів з аналогічною дією, здатних їх замінити: всі вони є абсолютно оригінальними і мають виражений клінічний ефект.

Підсумовуючи коротко практичні здобутки наукової роботи патріарха вітчизняної біохімії академіка Максима Федотовича Гулого, слід підкреслити, що він є рекордсменом серед науковців Інституту біохімії ім. О. В. Палладіна за кількістю впроваджених наукових розробок у виробництво. Він має 27 авторських свідоцтв і патентів. На жаль, не всі він встиг довести до виробництва в промислових обсягах (це вже справа його учнів). Але ті, що було впроваджено в сільське господарство, дали колишній країні (СРСР) величезні прибутки, а ті, що впроваджені в медицину, мали і мають значний соиіальний ефект. Деякі з них, дають навіть щорічний невеликий прибуток нашому Інституту, наприклад, антиалкогольний препарат «Медихронал», який виробляється ЗАТ «Фармацевтична фірма «Дарниця» (Київ) за Ліцензійним договором на знак для товарів і послуг «Медихронал» від 05.07.2000, власником якого $є$ Інститут біохімії ім. О. В. Палладіна НАН України.

I хоча опоненти Максима Федотовича Гулого стверджували, що існує небезпечне перетворення біохімії на прикладну науку, що впровадження наукових досягнень у практику призводить до втрати часу та уповільнення темпу досліджень, він всім своїм творчим життям доводив протилежне. В зв'язку з цим доречно навести його слова: «Чи можна розв'язати важливі практичні завдання без відповідних теоретичних, тобто фундаментальних досліджень? Чи можна було б без фундаментальних досліджень створити наш препарат «Карбоксилін» для тваринництва, чи «Намацит» $i$ «Коректин» для медицини, чи запропонувати методи лікування алкоголізму й наркоманії? ...Справді я вирішував прикладні питання, але не емпірично, а завдяки фундаментальним дослідженням, які проводились протягом десятиріч. I велися иілеспрямовано, а не з розрахунку на випадок: може, щось буде одержано». Тут він був абсолютно згодний з геніальним Луї Пастером, який писав, що в справжній науці «не існує прикладних наук, є тільки прикладання (використання) науки».

Максим Федотович Гулий прожив довге, плідне «біохімічне» життя. Історія науки знає небагато прикладів, коли вчений, маючи за плечима вже понад сто років, був сповненим творчої наснаги, енергії, планів, опікуючись не спогадами про славне минуле, а справами сьогодення i майбутнього. До подарованого природного розуму і таланту життя додало Максимові Федотовичу мудрості та скромності, доброти душі й сили духу. Він став унікальним взірцем вченого, який працею, талантом, усім своїм життям продемонстрував повну відданість науці та служінню народу. 
Нижче наводимо формули і тематичний план, написаний рукою Максима Федотовича незадовго до його сторіччя, а також щиро дякуємо старшому науковому співробітнику відділу регулящії обміну речовин Т. Т. Володіній за збереження иього унікального рукописного документа і слушні зауваження nід час обговорення рукопису нашої статті.

\begin{tabular}{|c|c|}
\hline 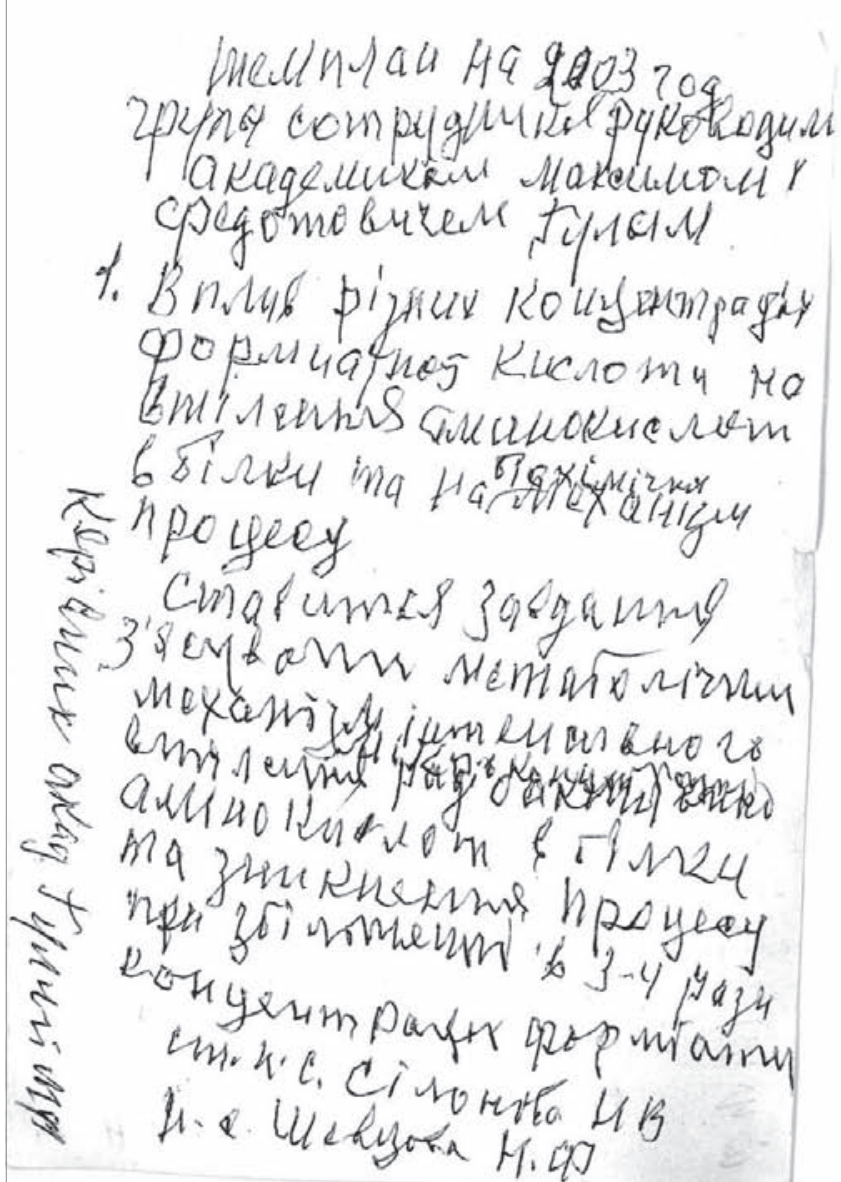 & 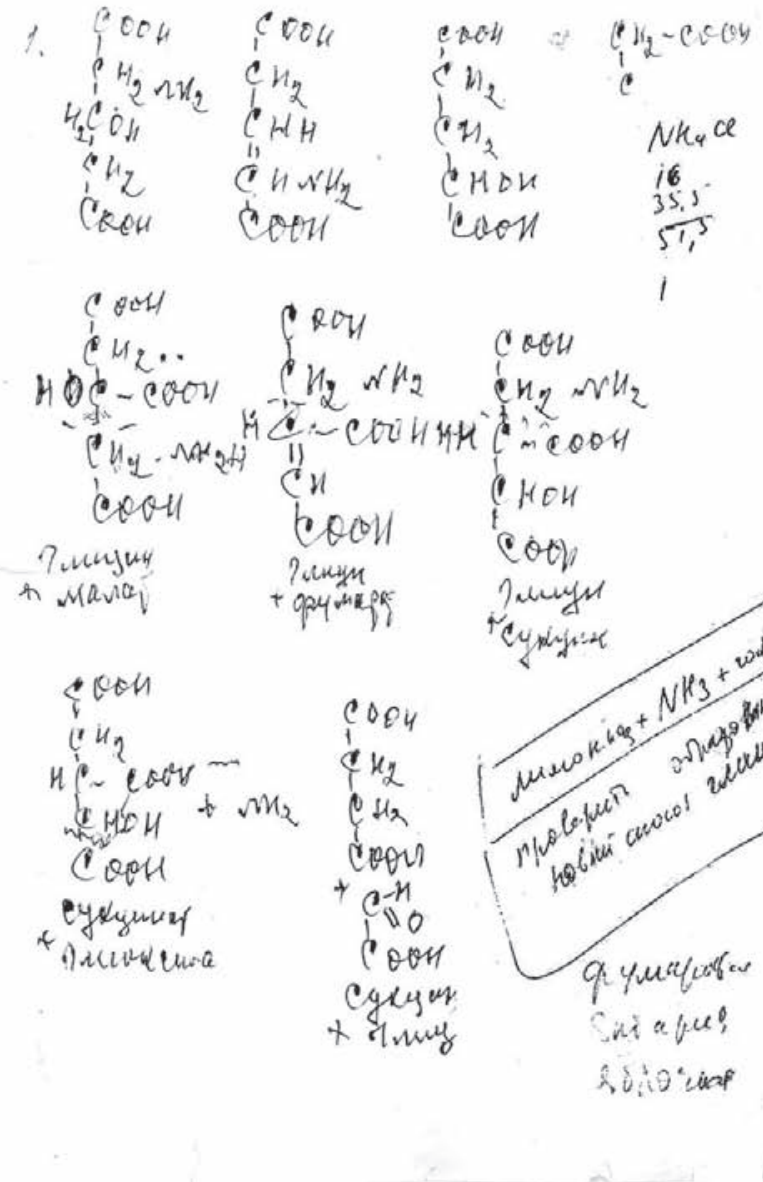 \\
\hline
\end{tabular}

В. М. ДАНИЛОВА, Р. П. ВИНОГРАДОВА, С. В. КОМІСАРЕНКО

Інститут біохімії ім. О. В. Палладіна НАН України, Київ; e-mail: valdan@biochem.kiev.ua

Отримано 17.04.2015 